\title{
Cosmos In The Art of Ex-libris
}

Assoc. Prof. Tevfik Inanç ilisulu Başkent University, Faculty of Fine Arts, Head of Department of Animation ilisulu@baskent.edu.tr

Full Length Paper Accepted 10 July 2018

\section{Abstract}

Ex-libris, as a form of art, has been produced not only by classical print methods but also by new techniques with the acceleration of technology. Throughout its existence, there have been various designs in different contexts. Just as music, nature and women, space is also a subject of ex-libris from the creative aspect of an ex-libris artist. Today, however, the boundaries have been pushed and it is well-known how tiny our solar system is in the universe. We can now explore vast distances and comprehend our distance to the other galaxies, the size of our universe and what our galaxy looks like. In this study, how "space", or in other words, how "the cosmos", which consists of all the matter and forms of energy in space, has been addressed in the art of ex-libris is studied.

Key words: Ex-libris, Cosmos, Design 


\section{Introduction}

Art and science have always been in a close relationship throughout history. Creativity was the point of origin for both. Creativity is the most valuable and surprising feature of human intelligence (Margaret, 1994, s.1). It is indispensable whichever branch of art or science it resides in. When we consider written history, scientist had been interested in art, or even artists had been regarded as scientists. Today, there are artist-scientists who work on and contribute to both science and art. These two combined fields are shaping the future. Breakthroughs in both science and technology are the products of pure creativity. For a scientists without the features of an artist, it is difficult to be creative. Art and science combined remains an enduring recipe for creativity, with their ability to merge humanities with imagination (Isaacson, 2017, s.9).

When we take education into consideration, especially in the universities' point of view, art and science appear as the spheres of influence of different faculties. These two fields have been considered separately either as science/engineering or fine arts. However when creativity is emphasized, it is clear that production and thought benefit from their connection and will continue to do so.

\section{Artist-scientist}

Fifteenth century was the time for invention, discovery and information to expand through new technologies. Obviously, the most well-known artistscientist in that era was Leonardo da Vinci. He had worked on many aspects of technology that we use today centuries before their appearance and made sketches of them. (Image 1, Image 2) (www.arthipo.com).

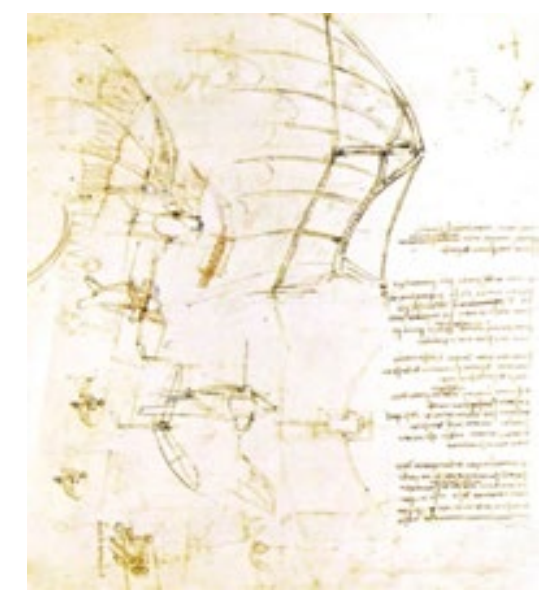

Image 2: Leonardo Da Vinci Drawing: Flying machine design drawings, Milan, Italy
Image 1: Leonardo Da Vinci Drawing: The design of the mechanism to move the wing, Torino, Italy 


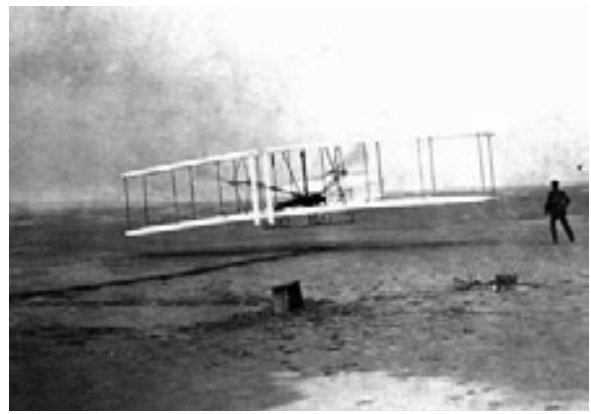

Image 3: The first successful flights of the Wright brothers, North Carolina
Through his creative, artistic and scientific thinking, Da Vinci broadened horizons for his predecessors. He might even led Wright brothers to their first successful flight on December 17th 1903 (Image 3).

Another prominent artist-scientist is Ernst Haeckel (1834-1919). He, as a biologist, worked on the theory of evolution and Darwin. He focused on plant and animal species. He has developed the theory of evolutionary development of species as the consequence of his work. In this way, he has contributed to Darwin's work and developed it, thus creating the basic law of bio-genetics. However, what made him influential was his elaborate drawings of his work and studies. Haeckel, who was a talented illustrator, created true works of art with his drawings of all his species and organisms of interest. He reached wider audience with his illustrations, made it possible for Darwin's theories and his main area, biology to get more attention from the society he lived in. (Image 4) (Haeckel, 1974, s.9-12).
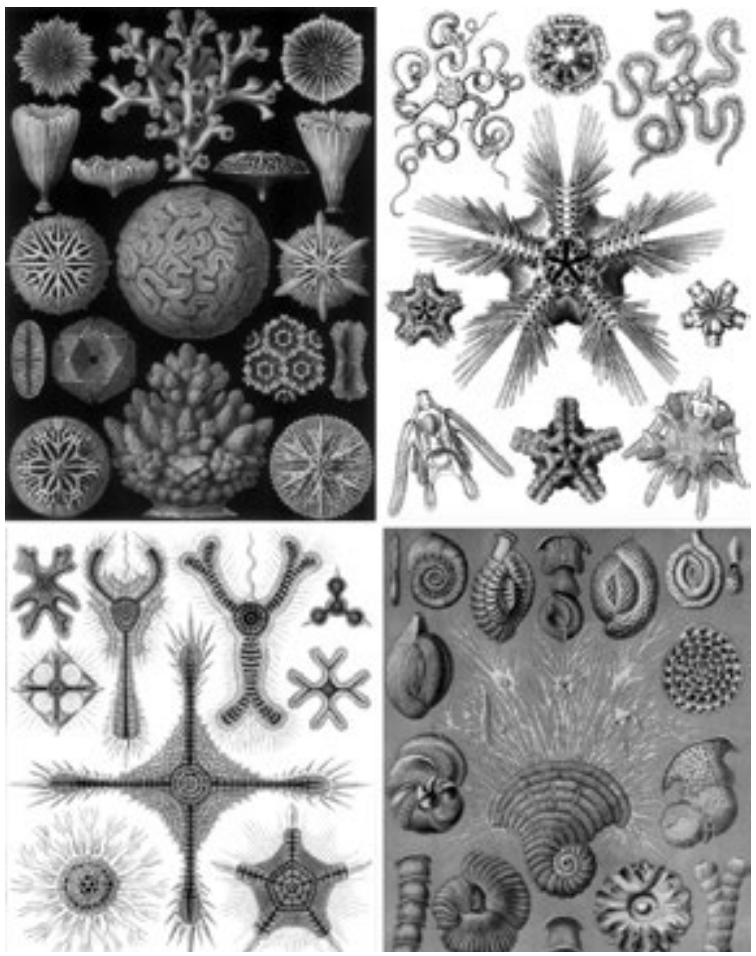

Image 4: Illustrations by Ernst Haeckel

Today, Theo Jansen is another example of prominent artists who combine art and science. While he was studying at university doing his major in physics, he left and started training in art and painting. He became well- 
known with his kinetic sculptures. His main purpose is to invent autonomous mechanisms powered by wind energy. He displayed his mechanical bots, which he calls "Beach Creatures", in his exhibition "Strandbeest: The Dream Machines of Theo Jansen". Viewers praised these "forest creatures" for their near-natural movement. Jansen states "I would like to create new forms of life, not a mimic of natural world as we know it or repeating past evolution". His designs inspire autonomous bot studies at present (Image 5).

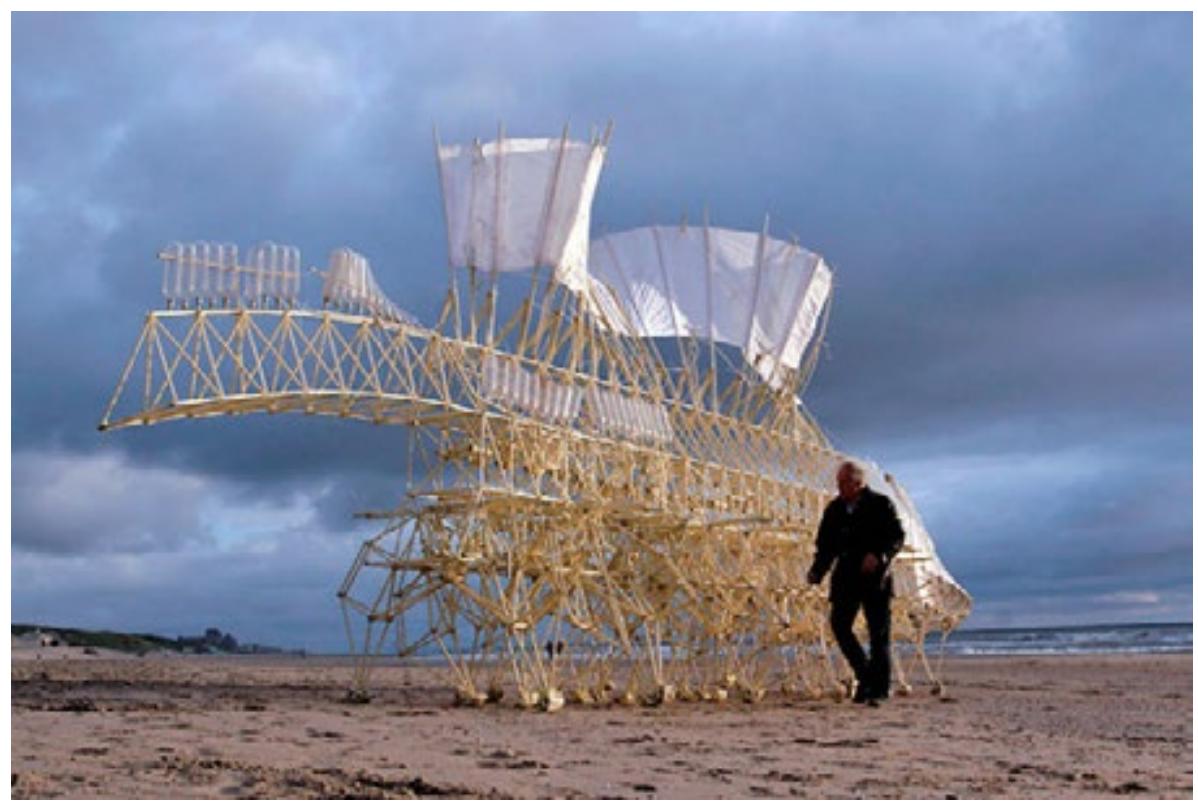

Image 5: Theo Jansen and Beach Creature

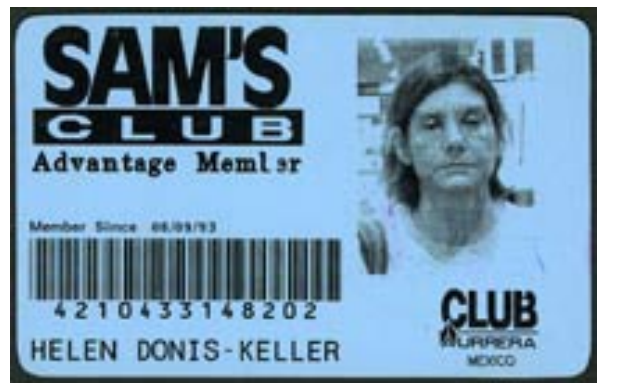

Image 6: Sam's Club Card
In reality, a perfect form of art which is created by science and science itself exist in the nature and cosmos. Another example of merging art and science is Helen Donis-Keller, who is an art and biology professor in Olin College. According to Keller, art and science view the world through their own lens and help us make sense of events and beings; the only difference is one has to do this by performing experiments and using objective data -because a scientist always has to be true and accurate- while the other presents their subjective, personal interpretation. Both publish and display their work and want us to view them, because their work is the fruit of a long and arduous effort. Her series called "Genotype: Phenotype" compared the possible genotypes that may emerge from her own DNA sequence and the phenotypes that these genotypes may create, came up with 176 different phenotypes based on 6 genotype sequences, and attempted to recreate 
these phenotypes using Photoshop on her own Sam's Club Card picture (Image 6, Image 7, Image 8) (gazetesu.sabanciuniv.edu).
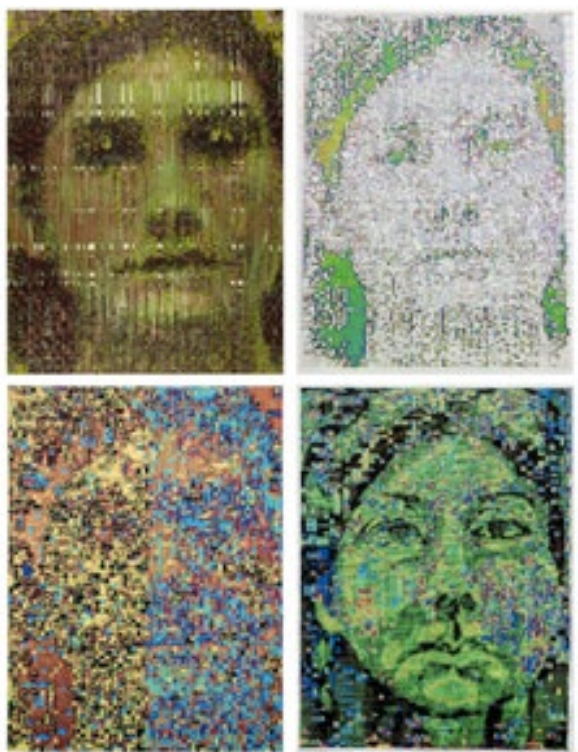

Image 7: Processed Photo

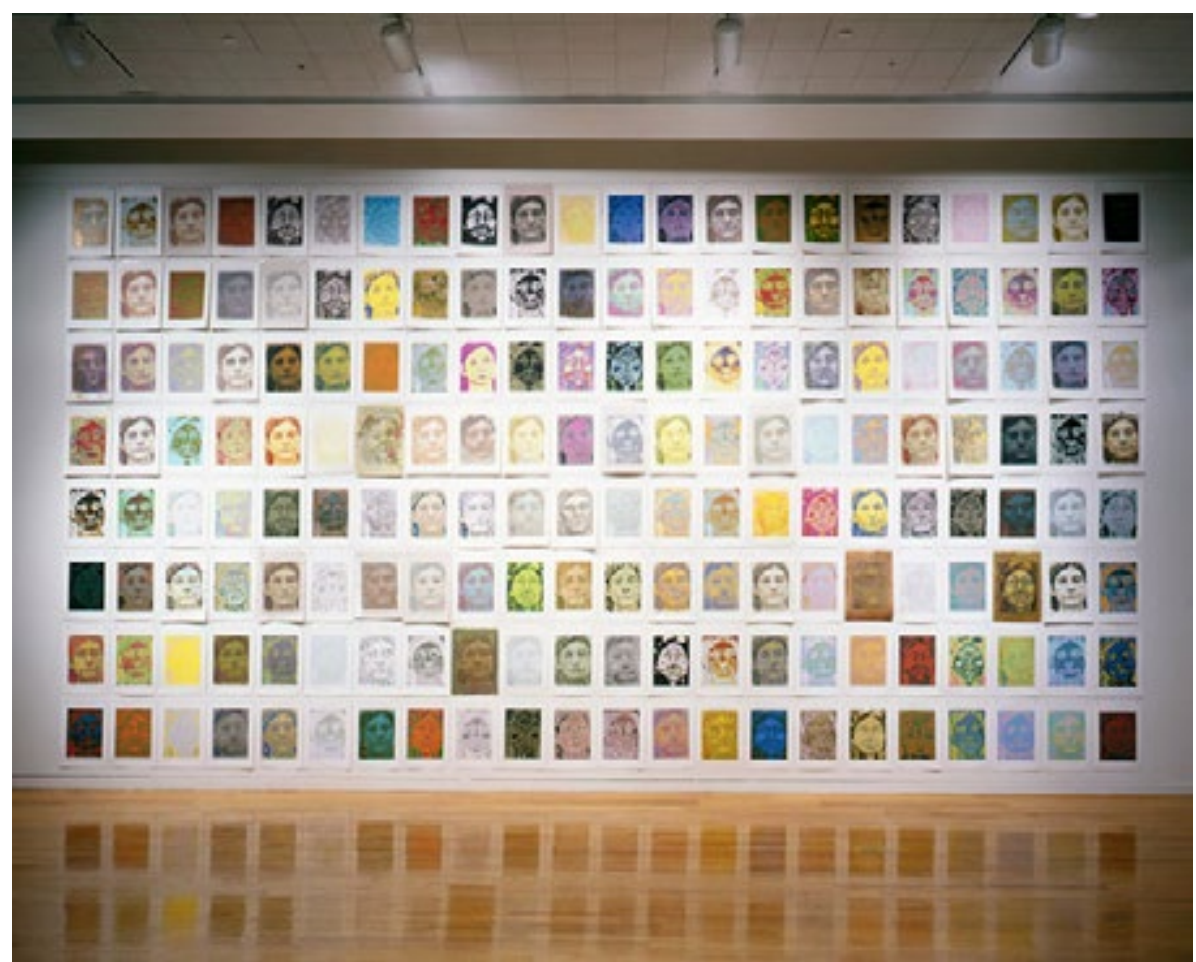

Image 8: Genotype: Phenotype Exhibition

Although ex-libris appeared as a needs graph, they are actually original works created through aesthetic concerns (Pektaş, 2014, s. 1-9). We can see that ex-libris designs as an art have developed through time in both production and content along with science and technology. With this development, different approaches like pop-up ex-libris, hologram ex-libris, 3D ex-libris are being experimented on (Image 9) (www.aed.org.tr).

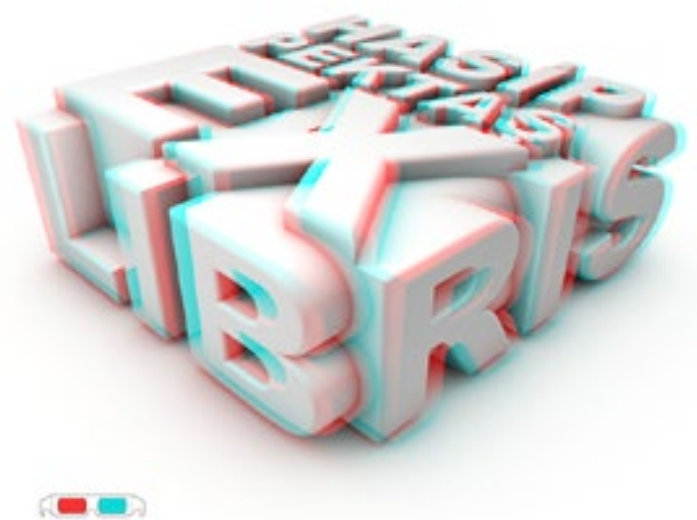

Image 9: Cem Gül (Turkey) / CGD / 2015 


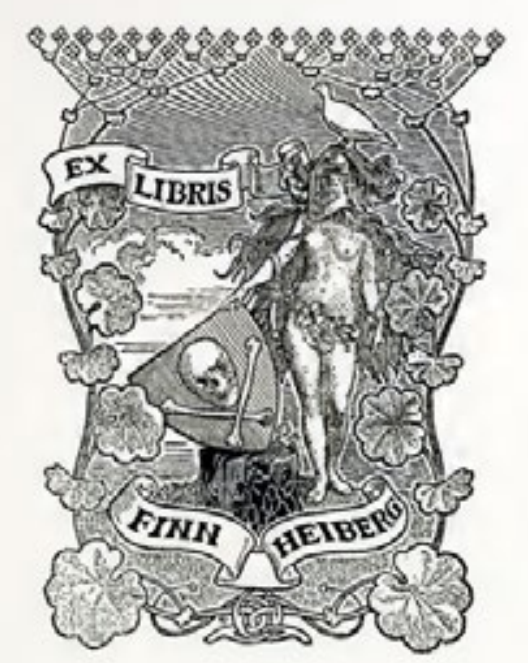

Image 10: Andreas Bloch (Norway) / X2 / 1917
When we consider the content of ex-libris works, woman and nature are the most prevalent subjects. Woman image has been frequently used throughout history in that it contains many messages. It can be claimed that it represents a great many subjects such as fertility, beauty, elegance, power, lust, erotism, sin and freedom. As a result, it has become a focus of interest for each branch of art throughout history.

In the art of ex-libris, this is also unavoidable and thus, woman is the most used subject. Ex-libris on the side (Image 10), symbolises woman image and erotism, yet expresses power, war and violence. The other ex-libris (Image 11) contains subjects like erotism, nature, science and book. Another ex-libris (Image 12) displays erotism, mythology, Adam and Eve relationship, wings of freedom and innocence through a toy zebra.

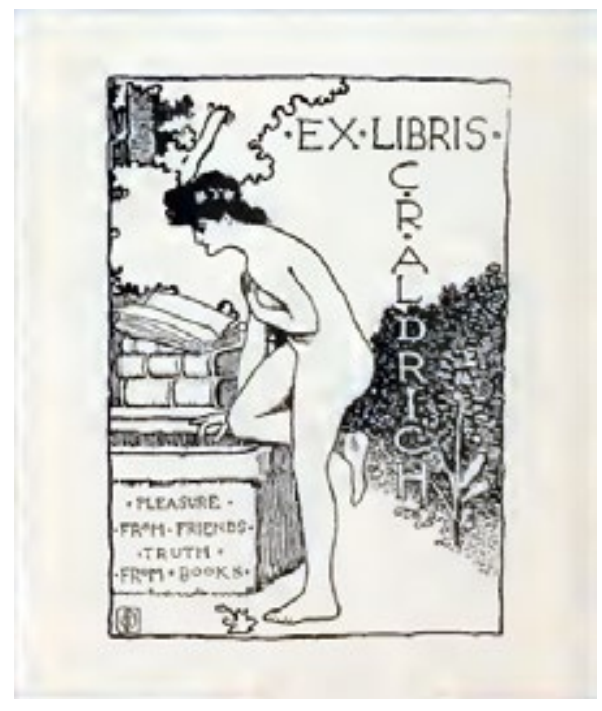

Image 11: Robert Cairns Dobson (America) / X2 / 1930

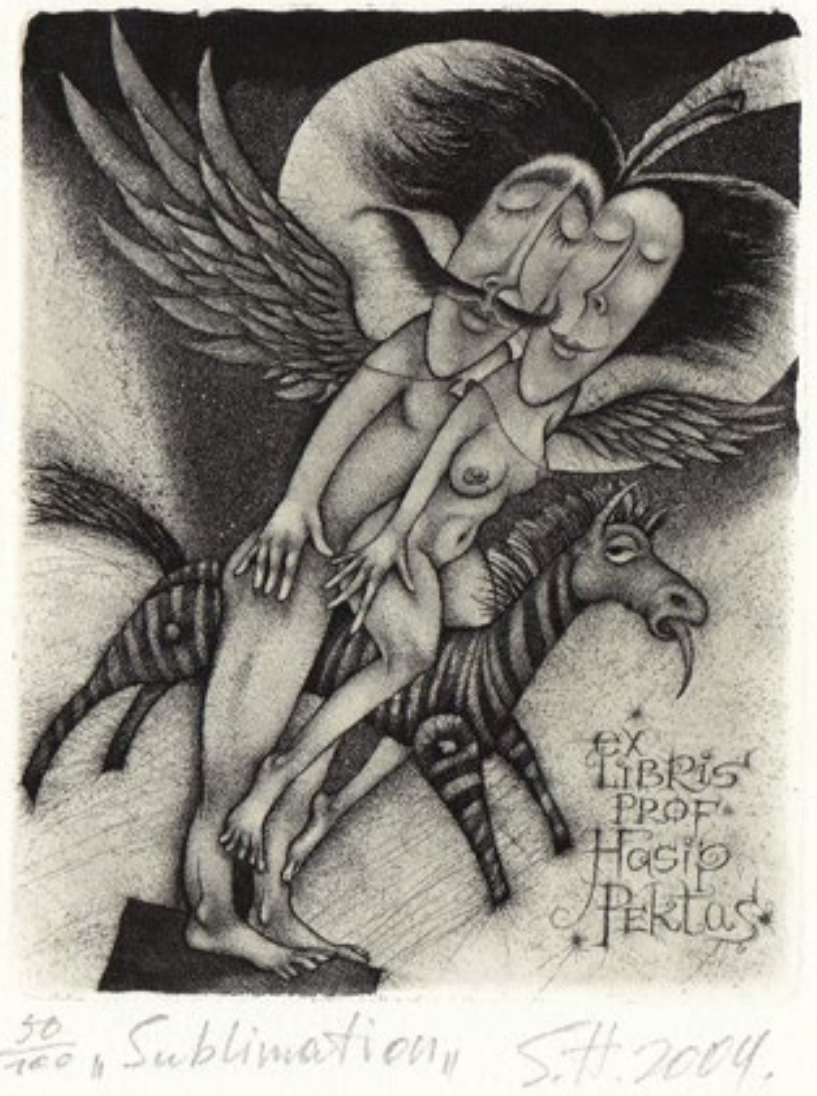

Image 12: Sergey Hrapov (Ukraine) / $\mathrm{C}_{3}-\mathrm{C}_{5}-\mathrm{C}_{7} / 2004$ 


\section{Buibrersammrung}

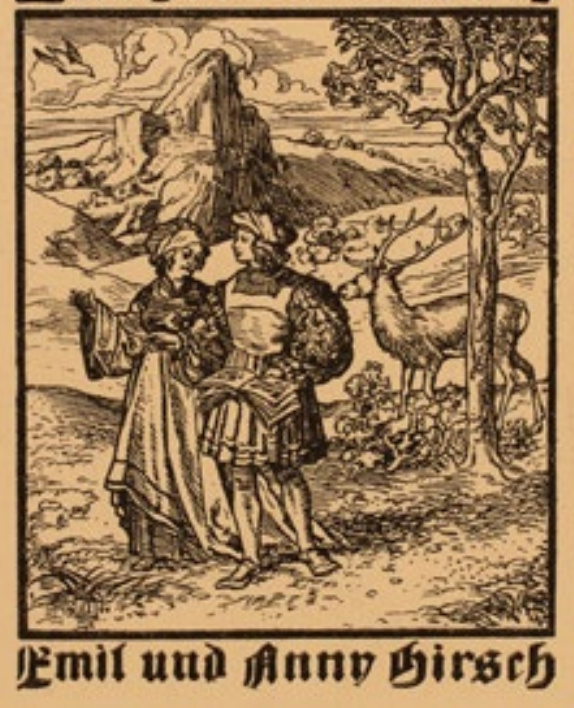

Image 13: Jos. Damberger (Germany) / P1 / 1900

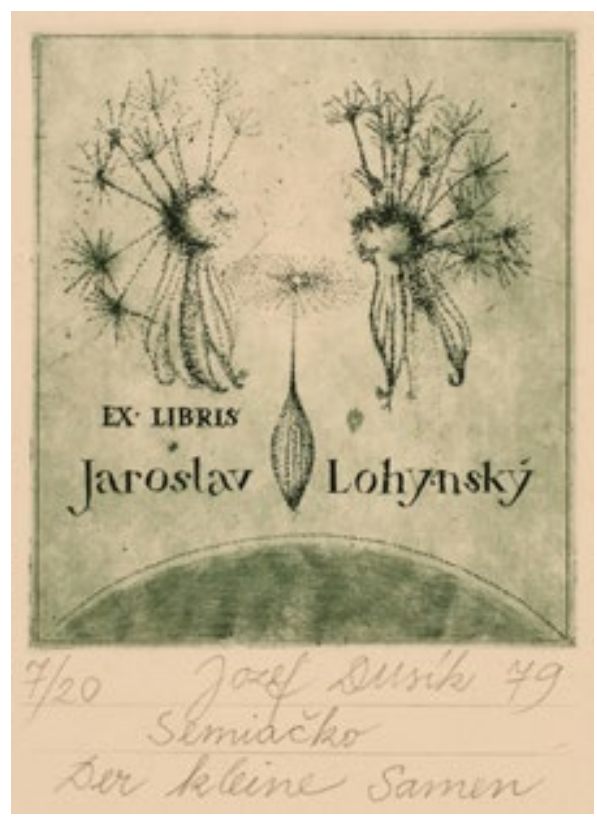

Image 14: Jozef Dusik (Czech Republic) / C3 / 1979
It is seen that although nature is another most common subject in ex-libris, it actually identifies with woman image. They both express the continuity of life, fertility, abundance and beauty. Ex-libris on the side (Image 13), where nature is chosen as the subject, man-woman figure is emphasized before nature and at the same time, we can say that the concept of knowledge is given in the image of a book. In the other ex-libris (Image 14), the fertility of nature is expressed along with the continuity of life by pollens spread in the wind.

\section{Ex libris and Cosmos}

The cosmos is all that is, or ever was, or ever will be. It contains the deep secret connections between living and inanimate beings, which form the universe. All of space, time, energy and matter exist inside the universe. (Sagan, 2016, s.17-18). The question here is "How could such a vast subject find its place in the art of ex-libris? We can generally see that the subjects of space and time are used within some works. If we take a closer look; in an ex-libris from 1957 (Image 15), a star and planets orbiting it can be seen. It might also be a black hole. If the artist's real intention was this in deed, then we can claim that cosmos is the main subject here.

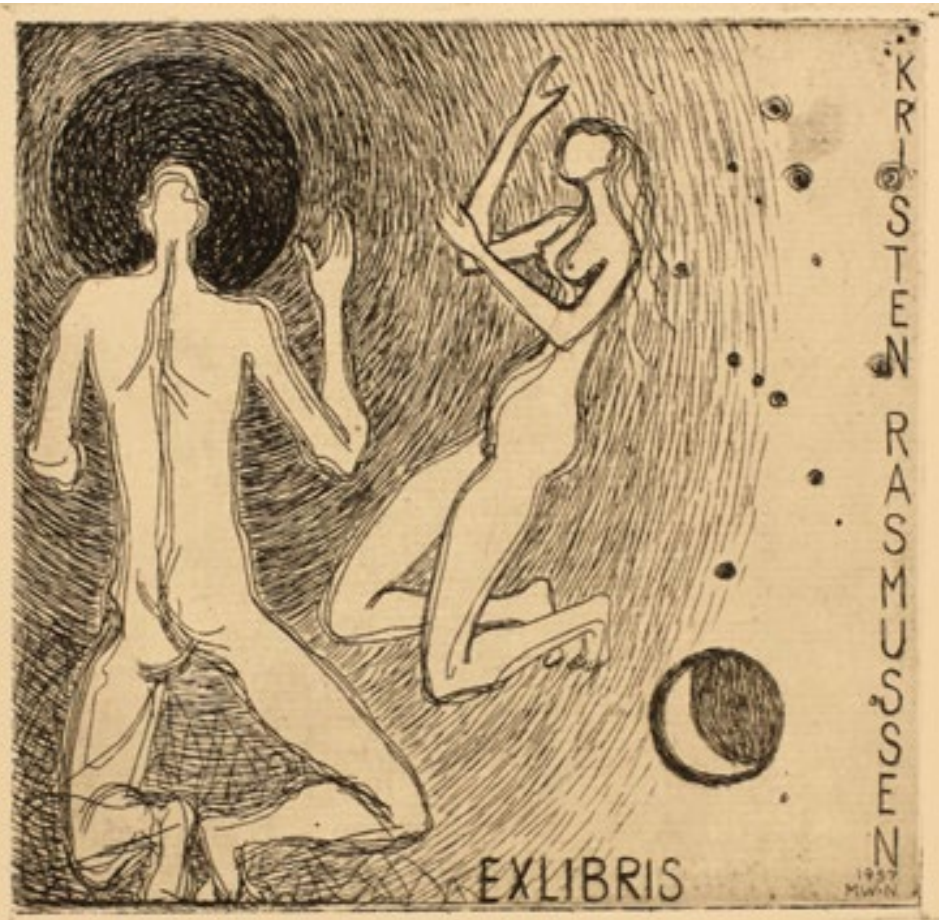

Image 15: Muggi Wille-Nielsen (Denmark) / C3 / 1957 


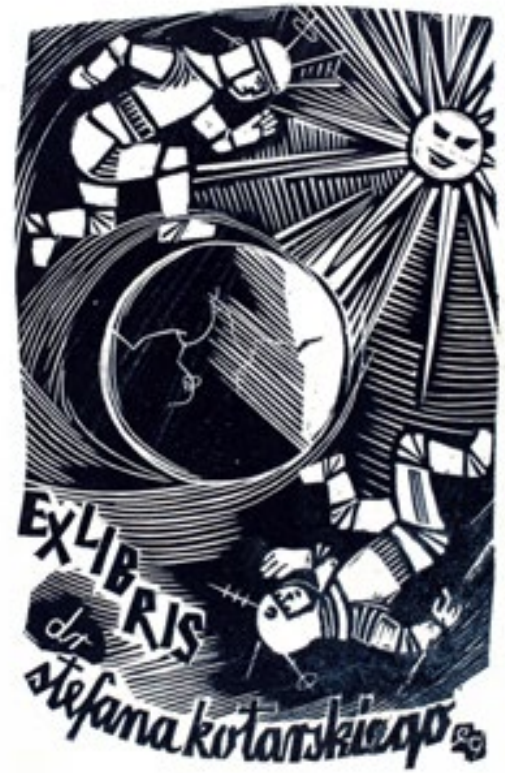

Image 16: Edward Grabowski (Poland) / $\mathrm{X}_{3}$ / 1963
In this ex-libris from 1963, the artist was clearly inspired by the first manned spacecraft in orbit sent by Russia in 1961 and the start of a space race between them and the USA (Image 16). With this in mind, it is seen that spacewalking astronauts, the Sun and the Earth are the center-focus.

By 1969, mankind had set foot on the Moon and this became the turning point for space science and cosmos. Many artists were influenced by this breakthrough and used it as a subject in their works of art. In an ex-libris from 1970 (Image 17), the artist experimented on something contemporary by illustrating an astronaut on the moon and his spacecraft.

In those years, people's interest in sending humans to space and space launches caused a boom in the sales of toys related to space. The artist, influenced by this phenomenon, illustrated an infant with a toy space rocket in his hand in his work from 1973. Here, the child is comparing his toy rocket to a real one (Image 18).

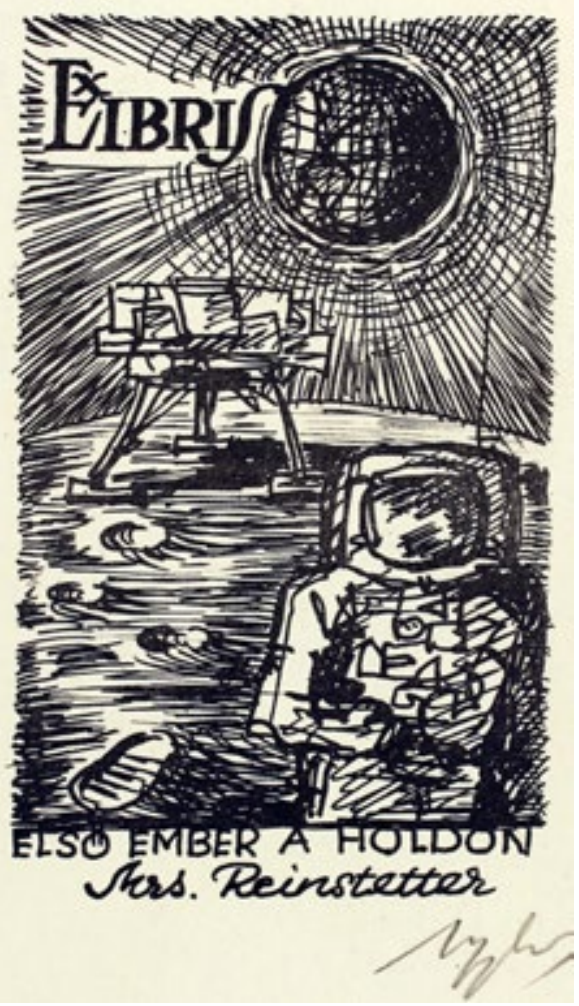

Image 17: Laszlo Lazar Nagy (Hungary) / P1 / 1970

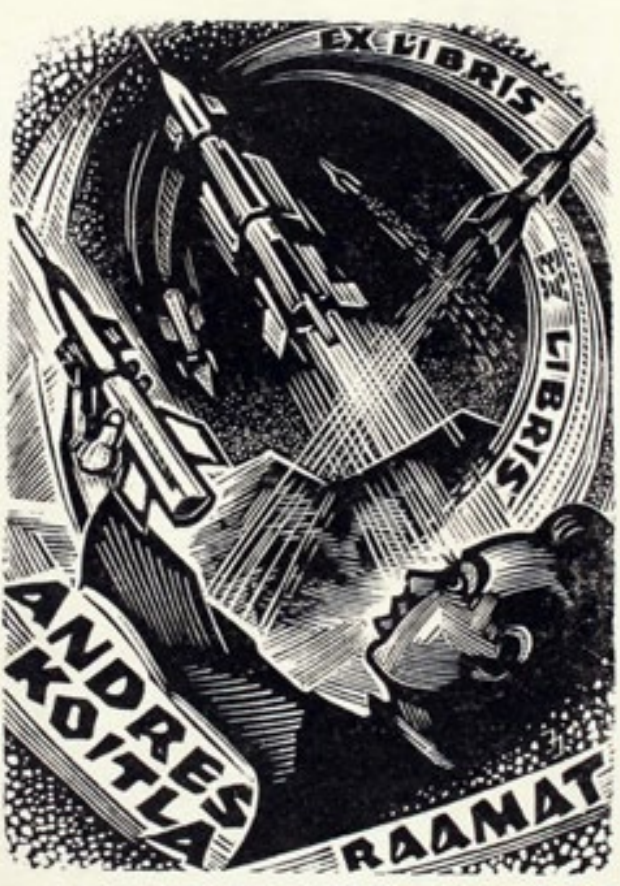

Image 18: Johannes Juhansoo (Estonia) / X1 / 1973 


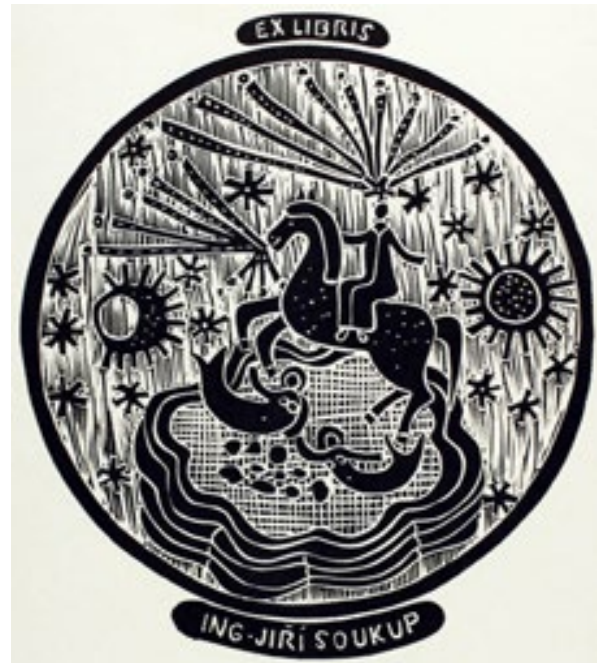

Image 19: Jana Krejcova (Czech Republic) / X3 / 1975

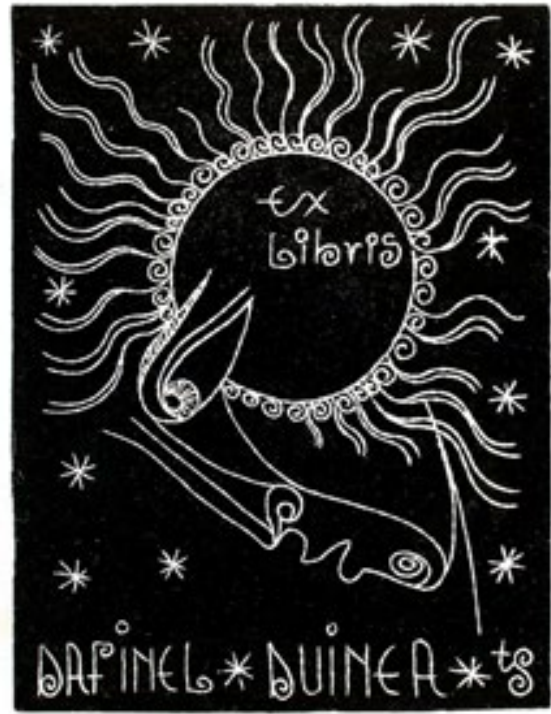

Image 20: Tit Simionescu (Romania) / C3 / 1979
The concept of cosmos in ex-libris has been expressed in a variety of forms. Although the subject of ex-libris works from 1975 and 1979 was space and cosmos (Image 19, Image 20), they actually utilize astrology, which is defined as interpreting the locations and movements of stars to foretell future.

By 1980's, sending satellites to orbit and rockets to other planets began influencing artists. In the ex-libris on the side (Image 21), it is shown that while a satellite is being sent to the orbit, a rocket is launched to another planet.

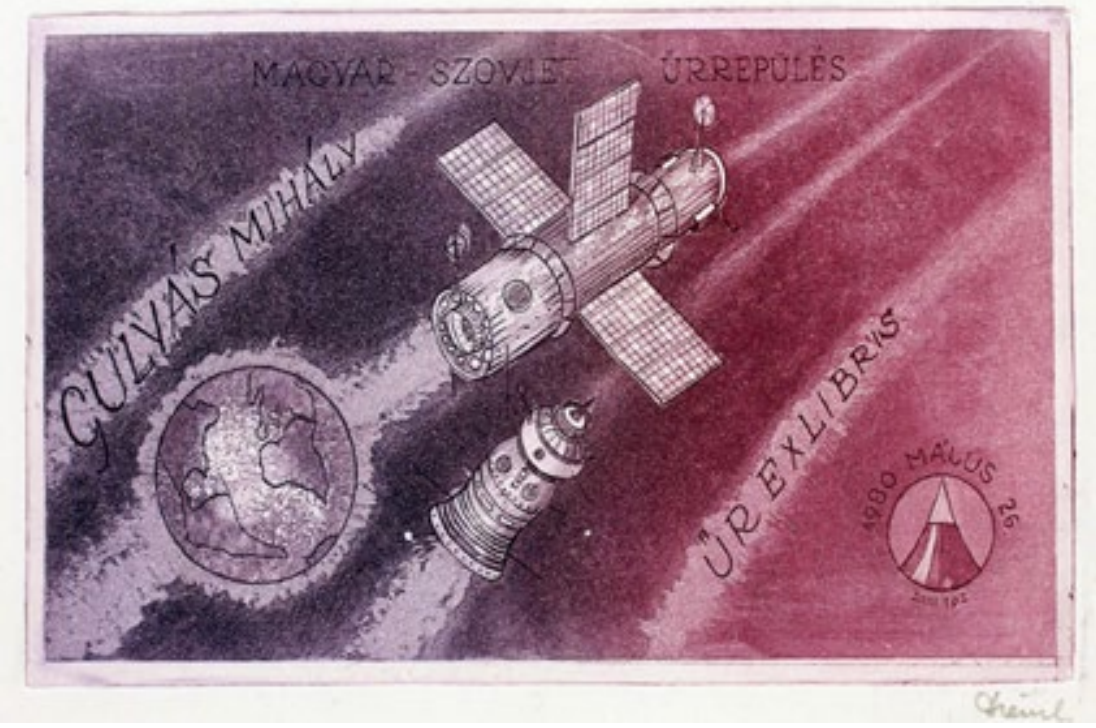

Image 21: Victor Daniel (Hungary) / C3 / 1980

\section{Conclusion}

Cosmos, which is defined as a universe in order, presents us infinite and inexhaustible knowledge. Developing technology and possibilities trigger our curiosity also. Georges Méliés directed "A Trip to the Moon” in 1902 with incredible camera tricks and 67 years later mankind landed on the Moon. Méliés influenced the way scientists think and may have even lead them with his film. The infinite knowledge of cosmos creates new opportunities for both artists and scientists. This understanding may lead ex-libris artists to come up with new, captivating and unique designs in the infinite horizon of the cosmos. 
These creative designs may inspire scientists and lead them. As Prof. Dr. Carl Sagan made space science a popular topic in 1980's thus inciting interest of cosmos in people, todays artists may help ex-libris become widely known by benefiting from cosmos, which is actually a day trip to learn about ourselves.

\section{References}

Haeckel, E. (1974). Arts Forms in Nature (Dover Pictorial Archive Series). New York: Dover Pubications.

Isaacson, W. (2017). Leonardo Da Vinci. New York: Simon \& Schuster.

Margaret, B. (1994) Dimensions of Creativity. London: The MIT Press Cambridge.

Pektaş, H. (2014). Türkiye'de Ekslibris. Ex-librist Dergisi, 1(1), 1-9.

Access address:

http://dergipark.gov.tr/download/article-file/207703

Sagan, C. (2016). Kozmos Evrenin ve Yaşamın Sırları (R. Aşçıŏlu, Çev.). istanbul: Altın Kitaplar.

\section{Electronic References}

www.arthipo.com. Accessed: 11.05.2018

https://www.arthipo.com/artblog/unlu-klasik-tablolar/leonardo-da-vincinincizimleri-taslaklari.html

www.bbc.com. Accessed: 14.05.2018

https://www.bbc.com/turkce/ozeldosyalar/2014/12/141205_vert_cul_ yuruyen_iskeletler

gazetesu.sabanciuniv.edu. Accessed: 15.05.2018

http://gazetesu.sabanciuniv.edu/tr/2016-03/bilim-sanatla-bulusursa

www.aed.org.tr. Accessed: 19:05.2018

http://www.aed.org.tr/tr/galeri/page/3 